\title{
DETERMINATION OF FLUOORINE BY PROTON- INDUCED GAMMA-RAY EMISSION (PIGE) SPECTROMETRY IN IGNEOUS AND METAMORPHIC CHARNOCKITIC ROCKS FROM ROGALAND (S. W. NORWAY)
}

\author{
I. ROELANDTS,* G. ROBAYE,** G. WEBER,* J. M. DELBROUCK,**. \\ J. C. DUCHESNE* \\ ${ }^{*}$ Geology, Petrology and Geochemistry \\ **Experimental Nuclear Physics \\ University of Liège, B-4000 Sart Tilman (Belgium)
}

(Received December 12, 1986)

\begin{abstract}
More than 200 specimens from different occurrences of the Rogaland igneous complex and surrounding granulite facies metamorphic rocks (S. W. Norway) have been analysed by a direct non-destructive proton induced gamma-ray emission (PIGE) technique. The fluorine contents vary from $<25 \mathrm{ppm}$ to $3500 \mathrm{ppm}$. There is a good correlation between the concentration of fluorine and that of phosphorus for igneous rocks, suggesting a control of apatite on the F content. In metamorphic rocks, amphibole and biotite besides apatite are the principal cencentrators of fluorine indicating that fluorine in the system is controlled by granulite facies metamorphism conditions.
\end{abstract}

\section{Introduction}

Fluorine is the thirteen element in order of abundance in crustal rocks of the Earth, with an average content of $625 \mathrm{ppm} / 1 /$. It is an important constituent of the fluid phase associated with granitic rocks and various mineralizations. Its behaviour in the upper part of the crust, where these rocks generaliy occur, has been extensively studied /2/. In the deeper part of the crust, it is less well documented. In recent years, its importance has however been emphasized as a possible major constituent besides $\mathrm{CO}_{2}$ of the fluid phase in equilibrium with igneous and metamorphic rocks of the granulite facies and stressed the need of further geochemical data in these materials. This paper reports the preliminary data of a geochemical study of fluorine in the granulite facies rocks from the Rogaland Province in S. Norway.

\section{Analytical method}

Colorimetry and specific ion-electrode, and to a lesser extent radiochemical neutron activation analysis are commonly used. In all these techniques the samples must be dissolved and chemical elimination of potentially interfering elements must be carriea

\footnotetext{
:Research Associate of the National Fund for Scientific Research (Belgium)
} 


\section{ROELANDTS et al.: DETERMINATION OF FLUORINE}

out, that restricts the analysis of a large number of samples in reasonable time as often required in geochemical studies. BREWERS and FLACK /3/ were the first to demonstrate that proton induced gamma ray emission (PIGE) spectrometry was capable of measuring fluorine in rock samples. However, the place of the PIGE technique is not yet established in the geosciences and geochemical data by this method are still scarce $/ 4 /$.

The PIGE technique, currently being developed in Liège University $/ 5 /$, proved to be valuable for routine fluorine determination ranging from $:$ to ppm levels in geological materials of widely varying compositions including rocks, soils, sediments, minerals and ores $/ 6,7 \%$. The non-destructive PIGE method used here is based on the nuclear reaction

$$
{ }^{19} F(p, a y)^{16} 0 \text {. }
$$

\section{Equipment}

The experimental arrangement for PIGE basically consists of three components : a Van de Graaff accelerator, a vacuum irradiation chamber and a detection system with associated electronios for counting the $\gamma$ rays. It is schematically represented in Fig. 1 .

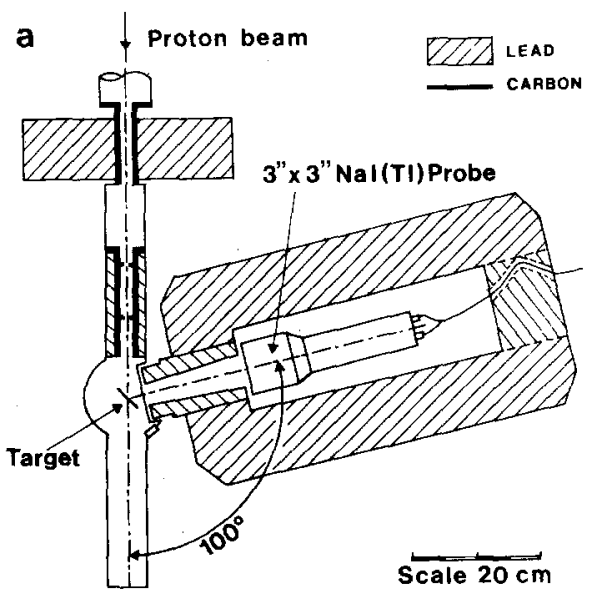

b

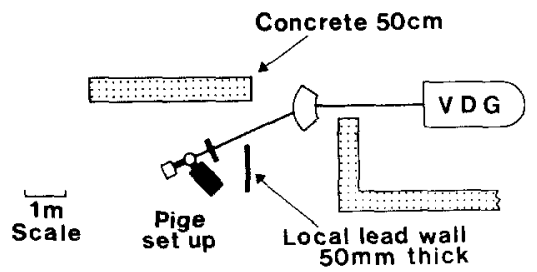

Fig. 1. Schematic diagram of the experimental set-up 
In this work a pellet of geological material mounted on an aluminum target ladder with 16 positions was bombarded in vacuum with a $500 \mathrm{nA}$ beam of $1.5 \mathrm{MeV}$ protons from the $3 \mathrm{MeV}$ Van de Graaff accelerator (HVEC) of the Experimental Nuclear Institute (University of Liège). This bombarding energy was found experimentally to give the best sensitivity. A beam spot area at the sample of about $20 \mathrm{~mm}^{2}$ was chosen. The emitted $\gamma$ rays were detected with a 3" $\mathrm{x}$ 3" $\mathrm{NaI}$ (TI) gamma probe ( $\triangle \mathrm{E} / \mathrm{E}=7 \mathrm{~g}$ FWHM) ca-. refully shielded and placed at a distance of $20 \mathrm{~cm}$ from the target with a $0.049 \mathrm{sr}$ solid angle at $100^{\circ} \mathrm{LAB}$. The resulting pulses were collected in a multichannel height analyser (IN90 Intertechnique) employed for data acquisition and analysis. Each sample required about 45 minutes of running time.

\section{Sample preparation}

The powajered rock sample (carefully weighed with a microbalance) was intimately mixed with graphite SP-IC powder (Union Carbide) in a 9:1 weight ratio and regrinded in an agate mortar. The mixture was transferred to a Beckman evacuable die and pressed at $4.10^{8 \mathrm{~Pa}}$ in a hydraulic press. A polypropylene film was placed between the pellet and the pressing surface to prevent any contamination and removed afterwards. The resulting pellet which was $13 \mathrm{~mm}$ in diameter and $1-2 \mathrm{~mm}$ thick proved to be easy to handle. For routine analysis, $200 \mathrm{mg}$ of mixture were prepared

(180 $\mathrm{mg}$ sample and $20 \mathrm{mg}$ graphite). C acted as a binder and also provided good conduction of the target.

Calibration was effected via primary powder standards. They were fabricated simply by adding. known quantities of sodium fluoride (Merck, AR grade purity) to pure quartz (Merck, AR grade purity) and agitating the whole in a Turbula system Schatz for 15 hours to ensure a uniform fluorine distribution. Three replicate pellets from each calibration standard were prepared following the procedure used for the rocks. The $\gamma$ ray intensity was a linear function of the fluorine content over a wide range of concentrations. "Blank" pelfets were made from pure quartz and graphite.

\section{Gamma ray spectrum}

A typical example of a gamma spectrum is shown in Fig.2. It is mainly composed by the 7.1 and $6.1 \mathrm{MeV}$ gamma-rays corresponding to the deexcitation of 160 nuclei produced in the reaction $19 \mathrm{~F}(\mathrm{p}, \alpha \gamma) 160$. Due to the pair production phenomenon-important at these energies - five gamma-peaks can be seen corresponaing to full energy loss, single escape and double escape. The 6.1 $\mathrm{MeV}$ peak was preferred for fluorine analysis because the base Iine may be more accurately drawn in this gamma spectrum region. For a uniform area sample, the concentration of fluorine can be determined directly from the counts of the gamma ray peak after background corrections and blank contribution subtraction. 


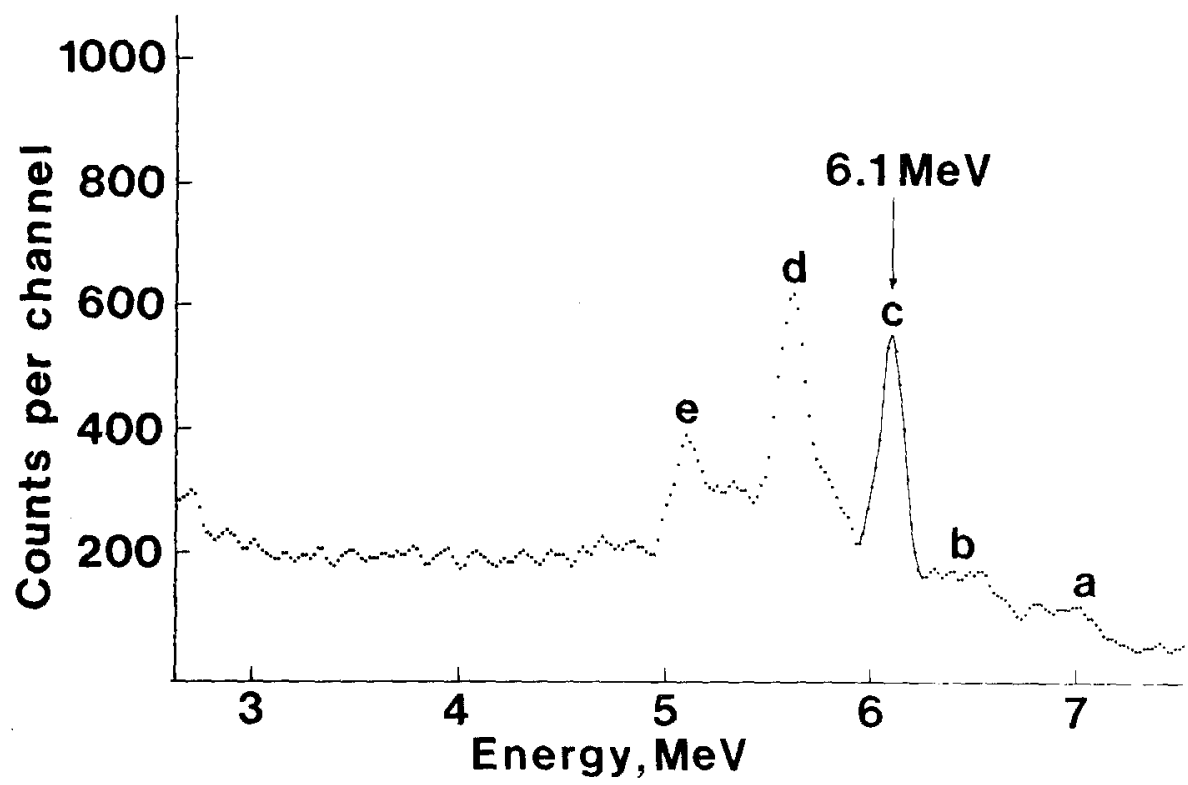

Fig. 2. Typical gamma-ray spectnm; a - 7.1-MeV full-energy peak; $b-7.1-\mathrm{MeV}$ single-escape peak; $c-7.1-$ $\mathrm{MeV}$ double-escape + 6.1-MeV full-energy peak; $\mathrm{d}-6.1-\mathrm{MeV}$ single-escape peak; $\mathrm{e}-6.1-\mathrm{MeV}$ double-escape peak

Limit of detection - Precision - Accuracy

A detailed evaluation of these three parameters which are important attributes when judging the merits of a method has been published elsewhere $/ 6,7 /$.

The limit of detection, defined here as the concentration corresponding to $3 \sqrt{B}$ pulses in the peak ( $B$ is the number of pulses in the background), was calculated to be equal to $25 \mathrm{ppm}$ of fluorine. This low limit of detection is mainly due to a careful study of the gamma shielding of the NaI(T1) probe. This value is quite acceptable for most geochemical applications.

The attained precision was found to be within acceptable limits: $10 \%$ at 100 ppm level, $6 \%$ at 1000 ppm level and $3 \%$ at I o concentration level of fluorine. In the present study, different pellets of the granodiorite GSP-I (U.S.G.S.) were systematically included in every irradiation. The mean value of our GSP-1 analyses was $3477 \pm 195 \mathrm{ppm}(\mathrm{n}=48)$.

Eighty internatioñal geochemical reference samples (GRS) from different organisms, including igneous, metamorphic and sedimentary silicates, carbonates, phosphates, minerals, soils and ores have been analysed to check the accuracy of our determinations $/ 6 /$. Most of our results were within $10 \%$ (or better) of the quoted values. This accuracy is quite satisfactory especialIy considering the range of variation of the available literature values. 


\section{Data}

206 igneous and 31 metamorphic rocks from Rogaland were analysed. This province has been extensively studied by P.MICHOT /8/ who unravelled the overall geological history and by many authors who have dealt with geochemical and isotopic aspects (see the review by DUCHESNE et a1. /9/).

The igneous rocks

The igneous rocks belong to the anorthosite suite and comprise anorthosite, leuconorite, norite, monzonorite, mangerite, quartz mangerite and charnockite (nomenclature after STRECKEISEN /10/), all members belonging to the charnockitic family.

Contrarily to famous provinces e.g. in the typical region near Madras in India / $11 /$ where charnockites were defined, Rogaland igneous charnockites have not been metamorphosed and thus have preserved their primary magmatic characters and geochemical features.

The igneous rocks are coming from the various geological units of the province. These one essentially comprise

(1) three large massif-type anorthositic bodies essentially made up of anorthosite (more than 90 of andesine plagioclase) with subordinate amounts of leuconorite and norite

(2) a layered lopolith (the Bjerkreim Sokndal massif) made up of a series of cumulates grading from anorthosite to mangerite and on top of the series quartz mangerite and charnockite.

(3) several large dykes and intrusions of overall monzonoritic characters, some of them varying in composition from norite to quartz mangerite $/ 12 /$.

The fluorine content of 206 rocks is summarized in Table 1. The most striking feature is the relationship between the $F$ and

Table 1

Fluorine and $\mathrm{P}_{2} \mathrm{O}_{5}$ contents of igneous rocks of the charnockitic family

Massif-type anorthosite anorthosite, leuconorite, norite

Bjerkreim-Sokndal lopolith

Layered anorthosite, leuconorite and apatite-free norite

Layered apatite-bearing norite

Layered mangerite

Quartz mangerite (tolivine)

Amphibole charnockite

Monzonoritic dykes and intrusions Antiperthitic norite ( \pm quartz)

Monzonorite

Monzonite / Mangerite:

Quartz mangerite / charnockite

$\begin{array}{ll}\text { Fppm } & \mathrm{P}_{2} \mathrm{O}_{5} 8 \\ <25 & <0.01 \\ 45-110 & 0.04-0.14 \\ 1570-2800 & 1.90-3.30 \\ 350-800 & 0.4-.0 .9 \\ 100-750 & 0.1-1.0 \\ 270-620 & 0.07-0.3 \\ 1370-2380 & 1.7-3.00 \\ 1320-2470 & 1.5-3.1 \\ 800-1380 & 1.0-1.7 \\ 370-630 & 0.4-1.0\end{array}$




\section{ROELANDTS et al.: DETERMINATION OF FLUORINE}

$\mathrm{P}_{2} \mathrm{O}_{5}$ contents of the rock, which is appeared to be linear in Fig.3. This clearly indicates that $F$ is essentially contained in the mineral apatite $\mathrm{Ca}_{5}\left(\mathrm{PO}_{4}\right)_{3}(\mathrm{~F}, \mathrm{Cl}, \mathrm{OH})$. This behaviour is well illustrated by the evolution in the Bjerkreim sokndal massif, where apatite suddenly rises in the norites from very low content $(0.04-0.15 \%) \mathrm{P}_{2} \mathrm{O}_{5}$ to the $\frac{5}{5}$ level as soon as it becomes a liquidus mineral in process of fractional crystallization which is invoked to explain the massif $/ 13,14 /$. Further on in the series of rocks, the apatite and $F$ contents decrease progressively. A similar trend is also observed in the dykes and intrusions where the apatite content decreases with the evolution towards monzonite/mangerite and quartz mangerite. Again the crystallization of apatite can account for such a behaviour in successive liquids $/ 12 \%$. The average $\mathrm{F} / \mathrm{P}_{2} \mathrm{O}_{5}$ ratio which can be deduced from the fig. 3 is $785.10^{-4}$ which corresponds to a $F$ content of the apatite of $3.4 \%$, a value which closely matches those measured by BAUMER et al. /15/ on apatite separated from BjerkreimSokndal norites.

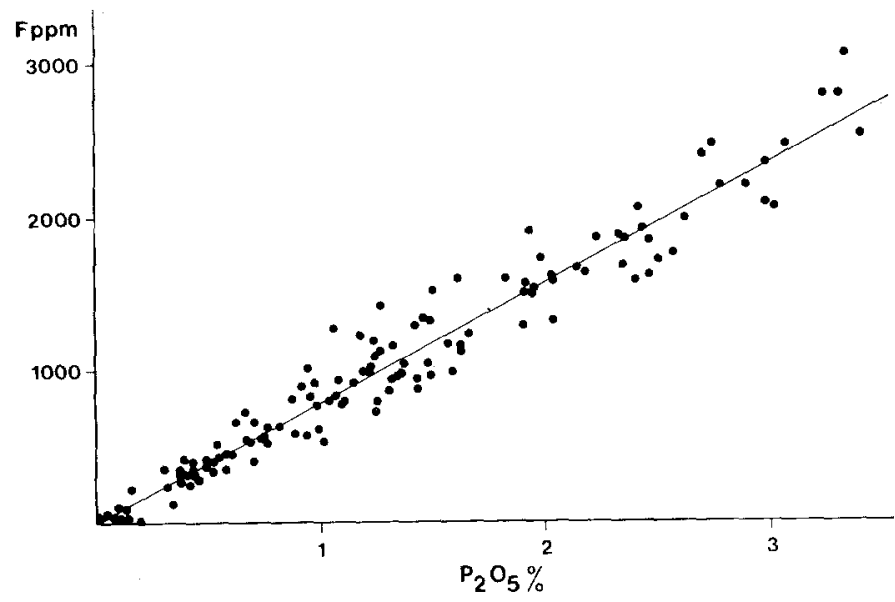

Fig. 3. $\mathrm{F}$ content vs. $\mathrm{P}_{2} \mathrm{O}_{3}$ in igneous rocks of the charnockitic family

\section{The metamorphic rocks}

A collection of rocks from the granulite facies terranes in which the igneous rocks were emplaced have been analysed. They essentially comprise metabasites, metapelites, granite-gneisses, metacharnockites and augen-gneisses. The results are reported in Table 2. Fig.4 clearly shows that contrarily to the igneous rocks, the apatite content is not the sole factor which controls the $F$ content of a rock.

In the metabasites, the presence of the hydroxy1-bearing minerals amphibole and biotite rises the $\mathrm{F} / \mathrm{P}_{2} \mathrm{O}_{5}$ values from 785 $10^{-4}$ in amphibole and biotite-free metabasites to $280010^{-4}$ and $1140010^{-4}$ in biotite-bearing and amphibole-bearing metabasites 
Table 2

Fluorine, $\mathrm{P}_{2} \mathrm{O}_{5}$ and $\mathrm{K}_{2} \mathrm{O}$ contents of metamorphic rocks

\begin{tabular}{|c|c|c|c|c|c|}
\hline & $\mathrm{n}(1)$ & $F(p p m)$ & $\mathrm{P}_{2} \mathrm{O}_{5}(\mathrm{q})$ & $\begin{array}{c}\mathrm{F} / \mathrm{P}_{2} \mathrm{O}_{5} \\
10^{-4}\end{array}$ & $\mathrm{~K}_{2} \mathrm{O}(\mathrm{z})$ \\
\hline \multicolumn{6}{|l|}{ Metabasites } \\
\hline Noritic & 3 & $190-500$ & $0.2-0.7$ & 785 & 0.38 \\
\hline $\begin{array}{l}\text { Amphibolite/amphibole- } \\
\text { bearing noritic } \\
\text { gneiss }\end{array}$ & 5 & $1230-2900$ & $0.1-0.3$ & 11400 & 0.78 \\
\hline $\begin{array}{l}\text { Biotite-bearing nori- } \\
\text { tic-gneiss }\end{array}$ & 4 & $1330-3570$ & $0.8-1.2$ & 2800 & 1.77 \\
\hline 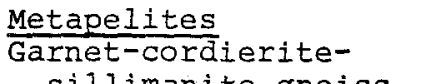 & & & & & \\
\hline silli & 3 & $\sim 30$ & $\sim 0.04$ & $\sim 750$ & 3.7 \\
\hline Granite-gneisses & 6 & $100-450$ & $0.04-0.14$ & $600-8200$ & 5.31 \\
\hline Meta-charnockites & 8 & $220-830$ & $0.05-0.42$ & $1050-4300$ & 4.92 \\
\hline Augen-gneisses & 2 & 1250 & 0.50 & 2500 & 3.06 \\
\hline
\end{tabular}

(1) number of specimens

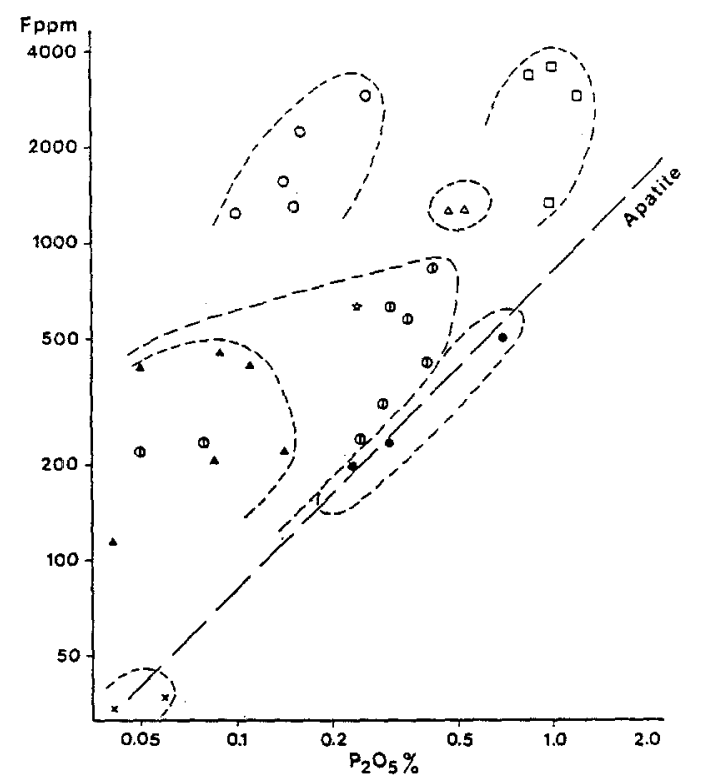

- noritic gneiss (metabasite)

o amphibole-bearing metabasite

$x$ metapelite (garnet-cordieritesillimanite gneiss)

A granite-gneiss

- metacharnockite

$\Delta$ augen gneiss

i average crustal composition

$\square$ biotite-bearing metabasite

Fig. 4. F content versus $\mathrm{P}_{2} \mathrm{O}_{5}$ in metamorphic rocks around the Rogaland igneous bodies. (The dashed line gives the $\mathrm{F} / \mathrm{P}_{2} \mathrm{O}_{5}$ ratio of the common apatite in igneous rocks) 


\section{ROELANDTS et al.: DETERMINATION OF FLUORINE}

respectively. It is generally admitted that the metabasites result from the metamorphism of basaltic igneous rocks. The $F$ content of common basaltic rocks/16/ in the range of $\mathrm{K}_{2} \mathrm{O}$ values reported here $\left(\mathrm{K}_{2} \mathrm{O}=0.38-1.77\right)$ varies approximately from $300 \mathrm{ppm}$ to $800 \mathrm{ppm}$. The high values reported here (up to $3500 \mathrm{ppm}$ ) inaicate that the chemical system did not remain closed with respect to $F$ during the metamorphism. Moreover, the systematic correlation with the hydroxyl-minerals suggests that the $\mathrm{F}$ and $\mathrm{H}_{2} \mathrm{O}$ were associated in the fluid phase which was carried into the system. during the granulite facies metamorphism.

The metapelites are strongly depleted in $F$ with respect to their non metamorphic equivalents. Averages in the range of 500$800 \mathrm{ppm} F$ are currently reported for shales /17/. This strongly suggests that $F$ has been removed from the system together with water during metamorphism.

The granite-gneisses and the metacharnockites show large and overlapping domains of $\mathrm{F}-\mathrm{P}_{2} \mathrm{O}_{5}$ variations. $\mathrm{F}$ appears to be contained not only in apatite but also in biotite and/or amphibole, which usually occur as minor constituents of the rocks. F is depleted in granite-gneisses with regards to the average crustal of $625 \mathrm{ppm}$ and the average value adopted for granites (about $800 \mathrm{ppm}) / 1,2 /$. Again this feature can result from granulite facies metamorphism. Some metamorphosed charnockites and augengneisses can however be more $\mathrm{F}$ and $\mathrm{P}_{2} \mathrm{O}_{5}$ enriched than granitegneisses.

We are grateful to the "Institut Interuniversitaire des Sciences Nucléaires" for the financial support of this research.

\section{References}

1. B. MASON and C. B. MOORE, Principles of Geochemistry, John Wiley, New York, 1982, p. 46.

2. J. C. BAILEY, Chem. Geol, 19 (1977) 1.

3. J. M. BREWERS, F. C. FLACK, Analyst, 94 (1969) 7.

4. R. O. ALLEN, P. J. CLARK Geochim. Cosmochim. Acta, 41 (1977) 581.

5. G. ROBAYE, J. M, DELBROUCK-HABARU, I, ROELANDTS, G. WEBER, L, GIRARD-REYDET, J. MORELLI, J. P. QUISEFIT, Nucl. Instr. Methods, B6 (1985) 558.

6. I. ROELANDTS, G. ROBAYE, G. WEBER, J. M. DELBROUCK, Geostand. Newsl., 9 (1985) 191.

7. I. ROELANDTS, G, ROBAYE, G. WEBER, J. M. DELBROUCK-HABARU, Chem. Geol., 54 (1986) to be puslished.

8. P. MICHOT, Norges Geol. Unders., 212g (1960) 1.

9. J. C. DUCHESNE, R. MAQUI, D. DEMAIFFE, in: The Deep Proterozoic Crust in the North Atlantic Provinces, A. C. TOBBI and J. L. R. TOURET (Eds.), D. Reidel Publ. Cy, 1985, p. 449.

10. A. STRECKEISEN, in: Geologie des domainęs cristallins, J. BELLIERE and J. C. DUCHESNE (Eds.), Société Géologique de Belgique, Liège, 1974, p. 349.

11. R. D. GAVRILIN, R. N. LEELANANDA, Ye. N. SAVINOVA, R, B. REDDI, Geochem. Intern. 21 (6) (1984) 35.

12. J. C. DUCHESNE, I. ROELANDTS, D. DEMAIFFE, D. WEISS, Contrib. Mineral. Petrol., 90 (1985) 214.

13. I. ROELANDTS and J. C. DUCHESNE, in: Origin and distribution of the elements, $L, H$. AHRENS (Ed.), Pergamon, 1979, p. 199.

14. J. C. DUCHESNE, Contrib, Mineral. Petrol,, 66 (1978) 175.

15. A. BAUMER, D. LAPRAZ, J. C. DUCHESNE, W. E. KLEE, IMA Communication, 13th General Meeting Varna (Bulgaria), Sep. 19-25, 1982, p. 171,

16. K. AOKI, K. ISHIWAKA, S. KANISAWA, Contrib. Mineral. Petrol., 76 (1981) 53.

17. R. ALLMANN, S. KORITNIG, in: Handbook of Geochemistry II-1, K. H. WEDEPOHL (Ed.), Springer Verlag Berlin, 1978, Ch. 9. 